\title{
Thermal, physical and mechanical properties of surface overlaid bark-based insulation panels
}

\author{
Dimitrios Tsalagkas $^{1}\left[\right.$ [ Zoltán Börcsök $^{1} \cdot$ Zoltán Pásztory $^{1}$
}

Received: 14 January 2019 / Published online: 17 July 2019

(c) The Author(s) 2019

\begin{abstract}
In terms of reduced energy consumption and simultaneously promoting woody biomass sustainability, researchers are seeking energy-efficient materials, originating from forestry and agricultural residues, for application in the building sector. In this study, bark-based panels overlaid on both surfaces with three different fibreglass types and two types of paper sheets were evaluated for potential utilization as thermal insulation panels. The proposed panels were then characterized regarding their thermal conductivity, physical, and mechanical properties such as density, water absorption, thickness swelling, surface soundness, bending strength and modulus of elasticity. It was found that thermal conductivity values ranged from 0.067 to $0.074 \mathrm{~W} /(\mathrm{m} \mathrm{K})$ for all the produced panels. As suggested from the results, fibreglass overlays exhibited improved performance compared to paper sheet overlaying. In addition, the fibreglass overlaid bark-based panels displayed promising characteristics as insulation materials. Finally, fibreglass woven fabric was found to be more beneficial than the mesh and mat fibreglass types.
\end{abstract}

\section{Introduction}

Buildings are reported to consume $40 \%$ of the EU's total energy demand and produce about $35 \%$ of greenhouse emissions. Therefore, in the background of meeting EU directives and targets on minimizing energy consumption and internal greenhouse gases, effective thermal insulation materials could endow this attainment. Concerning this purpose, i.e. the improvement of energy efficiency of existing and new buildings, this could be achieved either by enhancing the thermal performance of building envelopes such as walls, roofs and floors or by adopting efficient installations for heating, cooling electricity etc. (Pavel and Blagoeva 2018; Schiavoni et al. 2016).

Besides the increasing request for high thermal performance and 'near-zero-energy' consumption buildings, recent emerging trends and issues in the area of sustainable development and low environmental impact require the utilization of bio-based related materials rather than conventional ones such as mineral wool or petro-chemical based insulation mats (Torres-Rivas et al. 2018). Thermal insulation panels

Dimitrios Tsalagkas

dimitrios.tsalagkas@uni-sopron.hu

1 Innovation Center, University of Sopron, 4 Bajcsy Zs, Sopron 9400, Hungary made of biomass, also referred to as 'bio-insulations', have been increasing rapidly due to their availability as renewable, low-cost and eco-friendly materials. So far, several agricultural residues and forest wastes including wheat, rice, corn or date palm residues, wood shavings, cotton stalks, cork, recycled paper or other plant-based fibres such as reed, oil palm, sansevieria, flax, kenaf, cattail and hemp fibres (Asdrubali et al. 2015; Liu et al. 2017) have been investigated as alternative sustainable materials to attain insulation panels.

Each year, a significant amount of millions of tons of bark generated during wood processing is produced globally, emanating as a residual woody biomass in sawmills and wood-based industries (Aydin et al. 2017). The increasing research and development needs of introducing value added products made of wood waste materials have prompted many research efforts on the usage of bark residues besides burning them as energy fuel (Tudor et al. 2018). Researchers have focused their targets on the application of bark as adhesive additives, in pharmaceutical companies as well as in the manufacturing of various wood-based boards incorporating bark (Pásztory et al. 2016).

During 1960s, Martin (1963) investigated the thermal properties of bark specimens obtained from three pines and seven hardwood species by a heat probe method. According to this author, the bark displayed better thermal conductivity values 
compared to similar density wood samples. Lately, it has been investigated whether bark could be used as feedstock material to supply the insulation panels manufacturing industries. Kain et al. $(2013,2014)$ manufactured and tested insulation panels obtained from various softwood bark species for relatively low density boards $\left(<500 \mathrm{~kg} / \mathrm{m}^{3}\right)$. In like manner, Pásztory et al. (2017) examined the bark of black locust (Robinia pseudoacacia) trees as raw material for thermal insulation purposes.

One of the essential limitations on the exploitation of bark particles by wood industry is the resulting weakness of the mechanical properties of the manufactured wood-based panels or composites. A potential solution to overcome this issue could be the reinforcement of bark particle boards with common synthetic polymer fibres such as glass fibres. Inceptive research trials on fibreglass reinforced engineered wood products, started in the 1960s, with investigations focused on the bending properties of wood-fibreglass composite beams by Wangaard (1964) and Biblis (1965). Since then, fibreglass has been used by many researchers as external bonding, internal bonding, or near surface bonding reinforcement to increase the flexural stiffness and strength of wood composites. Such reinforced wood composites include MDF boards (Cai 2006), plywood (Biblis and Carino 2000; Mitzner 1973), laminated strand lumber (Moradpour et al. 2018), laminated veneer lumber (Bal 2014) and glulam timbers (Osmannezhad et al. 2014).

Both glass fibres and paper have been employed as insulation materials due to their low thermal conductivity values. The thermal conductivity of glass wool and paper are reported as $0.058 \mathrm{~W} /(\mathrm{m} \mathrm{K})$ (Cao et al. 2015) and $0.06 \mathrm{~W} /$ (m K) (Bøhmer 2001) under standard temperature $\left(25^{\circ} \mathrm{C}\right)$ and atmospheric pressure, respectively. However, the thermal conductivity of paper varies upon the paper sheet density, filler content, nature of the fibres, measuring methods and ambient conditions (Lavrykov and Ramarao 2012).

The overall objective of this study was twofold, (i) to examine the fiberglass and paper overlaying reinforcement effect on the mechanical performance of the bark-based boards and (ii) to evaluate the suitability of producing fibreglass and paper sheet overlaid bark-based boards as insulation panels in building construction. Therefore, the suggested bark-based panels were investigated in terms of thermal, mechanical and physical properties in this work. Furthermore, the effect of glass fibre reinforced polymer (GFRP) compared to paper sheet overlays on the properties of bark-based panels employing epoxy and UF as adhesives were further assessed and discussed.

\section{Materials and methods}

\subsection{Materials}

Poplar (Populus sp.) bark slabs without separation of innerand outer- bark, were peeled off from poplar trees at a local sawmill in Sopron, Hungary. After debarking, their moisture content was reduced to below $20 \%$ preceding to size reduction and following chopping into particles using a hammer mill equipped with $8-\mathrm{mm}$ screening holes. The collected bark particles were dried up until a final moisture content of 6-9\% was reached. Bark particles ranging from 0.5 up to $8 \mathrm{~mm}$ were selected as raw materials for the core layers in the insulation panel manufacturing.

For this study, three main commercial forms of fibreglass, i.e. fibreglass mesh (GFRP1), fibreglass mat (GFRP2) and fibreglass woven fabric (GFRP3) were used as surface layers in the analysis of the proposed panels (Fig. 1). The GFRP images were obtained with a Hitachi S3400 scanning electron microscope (SEM). Non-coated specimens were scanned under vacuum pressure of $70 \mathrm{~Pa}$ and an accelerating voltage of $15 \mathrm{kV}$.

Two types of paper sheets, one thicker double layer recycled paper (P1) and a thinner thermomechanical pulp (TMP) coated paper (P2) were bonded with urea-formaldehyde resin and pressed on both sides of the developed bark-based insulation panels. Their main properties, grammage (g) and tensile index (TI), were examined according to TAPPI T 410 (1998) and TAPPI T 494 (1996) standards, respectively (Table 1). The wetting behaviour of the paper sheet surfaces was characterized according to TAPPI T458 (2004) using a 68-76 PocketGoniometer PGX + model. Static measurements of contact angles (CA) and immersional wetting calculations $\left(\Delta G_{i}\right)$ were carried out with distilled water and DIM (3,3'-Diindolylmethane).

\subsection{Bark-based insulation panels production}

Four precent urea-formaldehyde resin DUKOL Ostrava s.r.o. (Kronores CB 1104 D) was used for the production of core-layer bark-based panels. Aqueous solution (35\%) of ammonium sulfate as hardener ( $3 \%$ solid content) was added as a catalyst. The bark particles were mixed with the resin system in a laboratory blender for 5 min to ensure homogeneous mixture. Thereafter, the resin-bark particles mixture was formed into a wood frame mould; the mixture was manually pre-compacted and then the frame was removed.

Bark based insulation panels with a size of $500 \mathrm{~mm} \times 500 \mathrm{~mm}$, a nominal thickness of $20 \mathrm{~mm}$ and a target density of $350 \mathrm{~kg} / \mathrm{m}^{3}$ were produced using a laboratory hot press (Siempelkamp). The pressing time was $18 \mathrm{~s}$ per final thickness in millimetre, and the temperature of the plates was $180^{\circ} \mathrm{C}$. The initial pressure of the plates was $2.86 \mathrm{MPa}$, which was reduced after $120 \mathrm{~s}-2 \mathrm{MPa}$, and after $240 \mathrm{~s}-1.15 \mathrm{MPa}$ to reduce the vapour pressure.

To examine the effect of external fibreglass reinforcement, each fibreglass type mat was overlaid on the top and bottom faces of the bark-based panels after hot pressing. The assembled GFRP structures were then bonded on core layers 

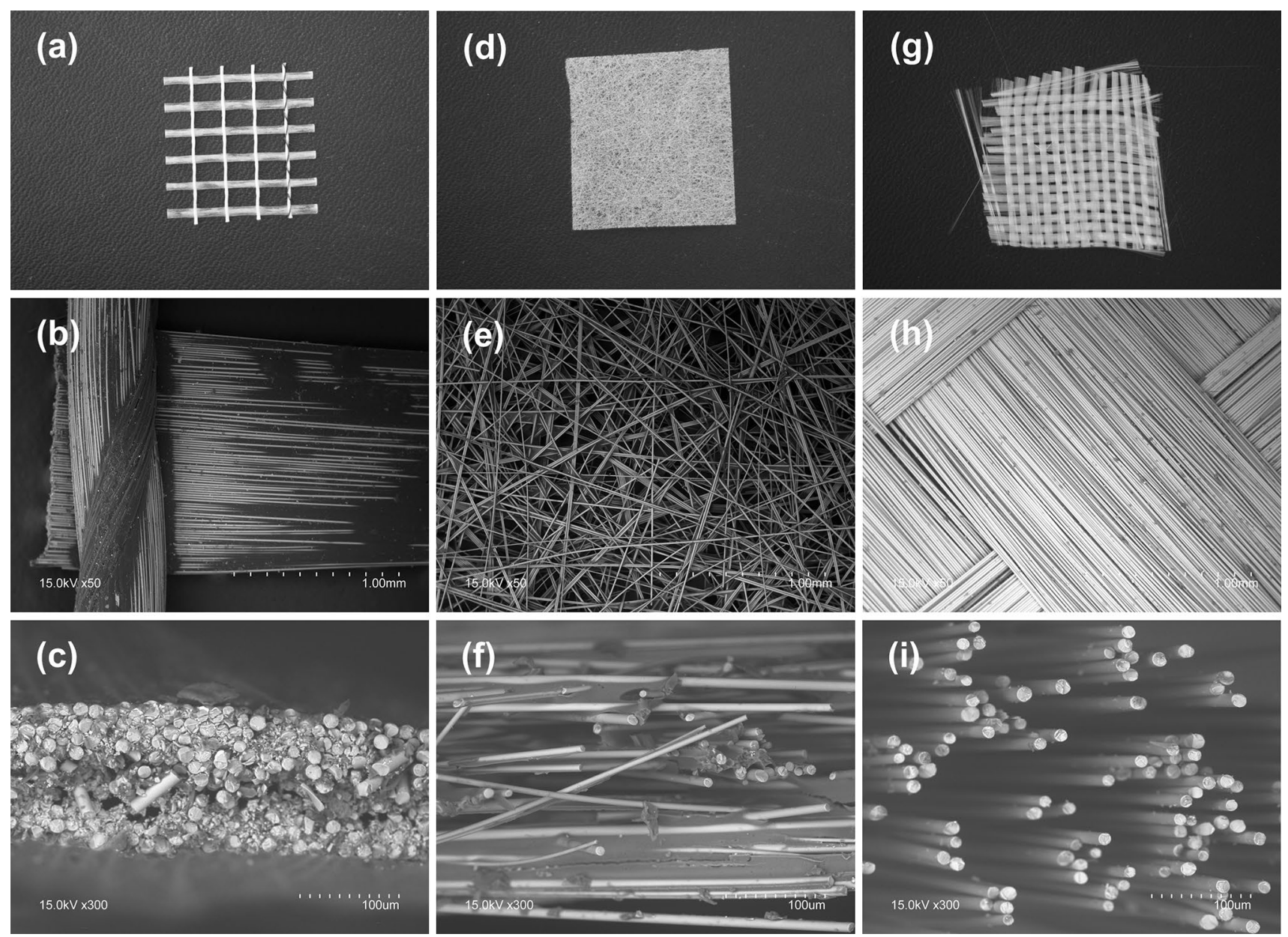

Fig. 1 Macroscopic images of GFRP1 (a), GFRP2 (d) and GFRP3 (g). In the second and third row, the surface can be seen; scale bar 1.00 mm $(\mathbf{b}, \mathbf{e}, \mathbf{h})$ and cross-section; scale bar 100 um $(\mathbf{c}, \mathbf{f}, \mathbf{i})$ SEM images of GFRP1, GFRP2 and GFRP3, respectively

Table 1 Sheet thickness and main properties of the paper sheets used in the research, according to TAPPI standards

\begin{tabular}{|c|c|c|c|c|c|c|c|c|}
\hline & \multirow{2}{*}{$\begin{array}{l}\text { Sheet thick- } \\
\text { ness }(\mu \mathrm{m})\end{array}$} & \multirow{2}{*}{$\begin{array}{l}\text { Sheet gram- } \\
\text { mage }\left(\mathrm{g} / \mathrm{m}^{2}\right)\end{array}$} & \multirow{2}{*}{$\begin{array}{l}\text { MD tensile } \\
\text { index }(\mathrm{Nm} / \mathrm{g})\end{array}$} & \multirow{2}{*}{$\begin{array}{l}\text { CD tensile } \\
\text { index }(\mathrm{Nm} / \mathrm{g})\end{array}$} & \multicolumn{2}{|l|}{$\mathrm{CA}\left({ }^{\circ}\right)$} & \multicolumn{2}{|c|}{$\Delta G_{i}\left(\mathrm{~mJ} \mathrm{~m}^{-2}\right)$} \\
\hline & & & & & Upper & Glued & Upper & Glued \\
\hline $\mathrm{P} 1$ & 278 & 194 & 60.19 & 22.28 & 109.8 & 71.4 & 24.66 & -23.22 \\
\hline P2 & 116 & 88.6 & 53.62 & 30.32 & 96.5 & 113.9 & 8.24 & 29.49 \\
\hline
\end{tabular}

$M D$ machine direction, $C D$ cross direction using a $2 \mathrm{~K}$ epoxy resin (Elan-tech EC 152; W152 HR) to form the panel. The epoxy-based adhesive was brushed onto the surface of bark panel and GFRP layers. The GFRP material which was equal in length to the panel dimensions, was glued onto it using a roller. After the hand lay-up process, bonding and simultaneous curing of fibreglass overlays to the core layer was made in a press under a pressure of approximately 2 bar and ambient temperature for $24 \mathrm{~h}$.

Paper overlaid insulation panels were prepared in a onestep process, since paper sheets were hot pressed simultaneously to form mat layer of bark particles. Paper sheets were applied to the bottom and upper surface during the manual formation of panel. Identical UF resin mixture as used in the bark particles, was spread on the surface of the papers using a brush before they were heat compressed. Before applying the overlaid sheets to the boards, dirt and dust were removed from the surface by using air.

For comparison purpose, only bark-based panels as control used as the core layer, were also investigated. At the end, a total of eighteen panels, three for each type were manufactured for the implementation of the measurements. Prior to testing, all panels were stored in a climate chamber at $20{ }^{\circ} \mathrm{C}$ and $65 \%$ relative humidity (RH) until an equilibrium moisture content was reached, which resulted in an 
average moisture content ranging from 7.29 to $9.12 \%$. The final appearance of the overlaid panels is illustrated in Fig. 2.

\subsection{Measurements}

\subsubsection{Thermal properties}

Thermal conductivity was measured across the thickness of the panel under a heat flow meter by using a custom-made, certified hot-plate apparatus. The thermal conductivity was calculated under steady state conditions by measuring the heat flux, as described by Fourier's law, according to the following equation:

$\lambda=\frac{d \cdot \phi_{q}}{\Delta T}$

where $\lambda$ is the thermal conductivity measured in watts per meter kelvin $(\mathrm{W} / \mathrm{m} \mathrm{K}), \Phi_{q}$ is the heat flux $\left(\mathrm{W} / \mathrm{m}^{2}\right), \Delta \mathrm{T}$ is the temperature difference across the specimen $(\mathrm{K})$ and $d$ is the thickness of the specimen $(\mathrm{m})$. Heat flow was measured in the $120 \times 120 \mathrm{~mm}$ midrange of the sample, whilst the full size of the specimens was $500 \times 500 \mathrm{~mm}$. To ensure heat flux parallel to the panel surface, additional $150 \mathrm{~mm}$ side insulation was used and the measurement was started after having the steady state conditions. The temperature difference between the hot and cold plate was set to $10^{\circ} \mathrm{C}$ and the mean temperature was $10^{\circ} \mathrm{C}$. For each panel type, thermal conductivity test was carried out on three specimens.

\subsubsection{Physical properties}

Bulk density ( $\rho$ ) was measured on the same samples used for the mechanical tests, according to European standard EN 323 (1993). The density of each panel was individually measured at current moisture content at time of mechanical bending test.
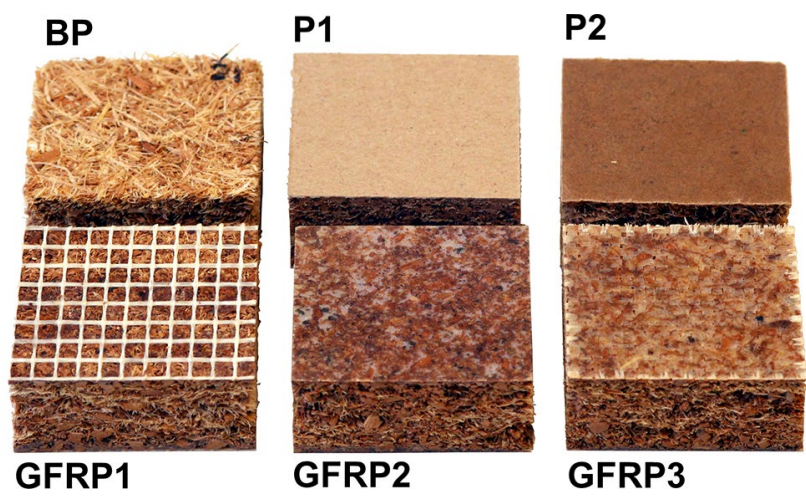

Fig. 2 Sample specimens (dimensions $50 \mathrm{~mm} \times 50 \mathrm{~mm} \times 20 \mathrm{~mm}$ ) of experimentally produced panels
Dimensional stability of the specimens regarding thickness swelling (TS) and water absorption (WA) after immersion in water for 2 and $24 \mathrm{~h}$ was calculated as suggested by the European standard EN 317 (1993). Twelve specimens with $50 \mathrm{~mm}$ by $50 \mathrm{~mm}$ dimensions were weighed and their thicknesses were measured with a level of accuracy of $0.01 \mathrm{~g}$ and $0.1 \mathrm{~mm}$, respectively.

\subsubsection{Mechanical properties}

The standard mechanical properties of the obtained barkbased panels were characterized using a universal testing machine Instron 5506. The characteristic flexural properties, i.e. bending strength (modulus of rupture, MOR) and modulus of elasticity (MOE) were determined using European standard EN 310 (1993). In addition, surface soundness (SS) tests were conducted to assess the quality of bonding between the overlaid mats and bark-based core layer (EN 311 1993). The specimens were prepared from different areas of the board and cut according to EN 326-1 (1994).

\subsection{Statistical analysis}

To assess the influence of overlaid GFRP and paper mat reinforcements on the bark-based panel properties, oneway ANOVA statistical analysis was performed using the Statistica13 software. All data were checked for normality (Shapiro-Wilk test) and homogeneity of variance (Levene's test). Post hoc tests were conducted with Tukey's HSD test method.

\section{Results and discussion}

\subsection{Thermal conductivity}

The thermal conductivity values of the overlaid bark-based panels, presented in Table 2, were calculated in the range of $0.067-0.074 \mathrm{~W} /(\mathrm{m} \mathrm{K})$, depending on the overlaying type. The proposed poplar bark-based panels (control and overlaid) can be characterized as an intermediate thermal performance mat as classified by Asdrubali et al. (2015). These values are in agreement with thermal conductivity values referenced in the literature for bark or other wood composite panels of similar densities and thicknesses. For instance, the thermal conductivity of larch (Larix decidua) bark panels reported by Kain et al. (2014) ranged from 0.069 to $0.093 \mathrm{~W} /$ (m K) depending on the panel's density. Likewise, Pásztory et al. (2017) reported that the thermal conductivity of panels made of black locust (Robinia pseudoacacia) was $0.0651 \mathrm{~W} /$ $(\mathrm{m} \mathrm{K})$. In addition, the thermal conductivity of low density 
Table 2 Results of thermal, physical and mechanical properties of the bark-based panels overlaid with paper mats

\begin{tabular}{|c|c|c|c|c|c|c|}
\hline & Control & $\mathrm{P} 1$ & $\mathrm{P} 2$ & GFRP1 & GFRP2 & GFRP3 \\
\hline \multicolumn{7}{|l|}{ Physical properties } \\
\hline$\rho\left(\mathrm{kg} / \mathrm{m}^{3}\right)$ & $336.80( \pm 22.95)$ & $360.24( \pm 17.57)$ & $353.06( \pm 14.67)$ & $413.07( \pm 23.77)$ & $395.69( \pm 18.66)$ & $403.71( \pm 26.97)$ \\
\hline $\operatorname{EMC~}(\%)$ & $8.88( \pm 0.17)$ & $9.12( \pm 0.15)$ & $7.60( \pm 0.36)$ & $7.29( \pm 0.28)$ & $7.51( \pm 0.56)$ & $7.64( \pm 0.23)$ \\
\hline $\mathrm{W}(\mathrm{wt} \%) \mathrm{n}=10$ & $218.37( \pm 28.03)$ & $159.32( \pm 6.98)$ & $210.87( \pm 42.45)$ & $147.03( \pm 24.04)$ & $1( \pm 23.53)$ & $1.83( \pm 22.96)$ \\
\hline TS $(\%)$ & $18.18( \pm 3.09)$ & $12.39( \pm 0.86)$ & $16.90( \pm 2.40)$ & $13.76( \pm 2.90)$ & $9.78( \pm 2.14)$ & $9.63( \pm 1.37)$ \\
\hline \multicolumn{7}{|l|}{ Thermal properties } \\
\hline$\lambda(\mathrm{W} / \mathrm{m} \mathrm{K})$ & $0.067( \pm 0.004)$ & $0.068( \pm 0.001)$ & $0.067( \pm 0.004)$ & $0.074( \pm 0.002)$ & $0.068( \pm 0.001)$ & $0.070( \pm 0.004)$ \\
\hline \multicolumn{7}{|c|}{ Mechanical properties } \\
\hline $\mathrm{SS}\left(\mathrm{N} / \mathrm{mm}^{2}\right) \mathrm{n}=10$ & $0.04( \pm 0.02)$ & $0.12( \pm 0.07)$ & $0.08( \pm 0.05)$ & $0.16( \pm 0.06)$ & $0.17( \pm 0.04)$ & $0.23( \pm 0.10)$ \\
\hline $\operatorname{MOR}(\mathrm{MPa}) \mathrm{n}=5$ & $0.54( \pm 0.17)$ & $2.12( \pm 0.18)$ & $1.43( \pm 0.24)$ & $2.54( \pm 0.81)$ & $2.82( \pm 0.68)$ & $4.45( \pm 1.98)$ \\
\hline $\operatorname{MOE}(\mathrm{GPa})$ & $0.28( \pm 0.08)$ & $0.99( \pm .0 .10)$ & $0.66( \pm .0 .06)$ & $1.95( \pm 0.40)$ & $1.36( \pm 0.19)$ & $2.86( \pm 0.48)$ \\
\hline
\end{tabular}

Numbers in brackets represent standard deviation. For WA, TS and flexural properties (MOR and MOE) measurements, identical specimens were used

$\rho$ bulk density, EMC equilibrium moisture content, $W A$ water absorption after $24 \mathrm{~h}, T S$ swelling in thickness after immersion in water for $24 \mathrm{~h}, \lambda$ thermal conductivity, $S S$ surface soundness, $M O R$ flexural strength, $M O E$ modulus of elasticity, $n$ number of specimens per board

wooden mats, composed of wood shavings and kenaf fibres was estimated with $0.069 \mathrm{~W} /(\mathrm{m} \mathrm{K})$ (Nakaya et al. 2016).

It is acknowledged that thermal conductivity is expected to increase proportionally to moisture content, temperature and density (Sonderegger and Niemz 2009; Troppová et al. 2015). Additionally, the wood-based panel manufacturing methods, wood-based materials and wood particle sizes, were also indicated as having a large impact on thermal conductivity (Sonderegger and Niemz 2012, 2009). As shown in Fig. 3, the thermal conductivity from all examined panels in this study was plotted as a linear function of density. Evidently, the higher the density of the overlaid bark-based panels, the higher was their thermal conductivity.

\subsection{Physical properties}

In this study, the core layer density of the panels was attempted to be kept identical in the range of $350 \mathrm{~kg} / \mathrm{m}^{3}$. Consequently, the increased and statistically higher density values observed on the overlaid panels can possibly be explained by the additional weight and thickness of the paper and fibreglass mats. The results of physical and mechanical properties of overlaid bark-based panels observed in this work are shown in Table 2.

As suggested by the results, control panels displayed high water absorption (217.89\%) and thickness swelling (17.67\%). In terms of reaction to water immersion (Fig. 4), statistical analysis showed that both thickness swelling and water absorption of P1 overlaid panels after $24 \mathrm{~h}$ were significantly lower than control $(\mathrm{p}<0.05)$ bark-based panels. Likewise, these panels displayed better results on water absorption of P2 overlaid panels, whilst thickness swelling of recycled paper was also significantly lower than that

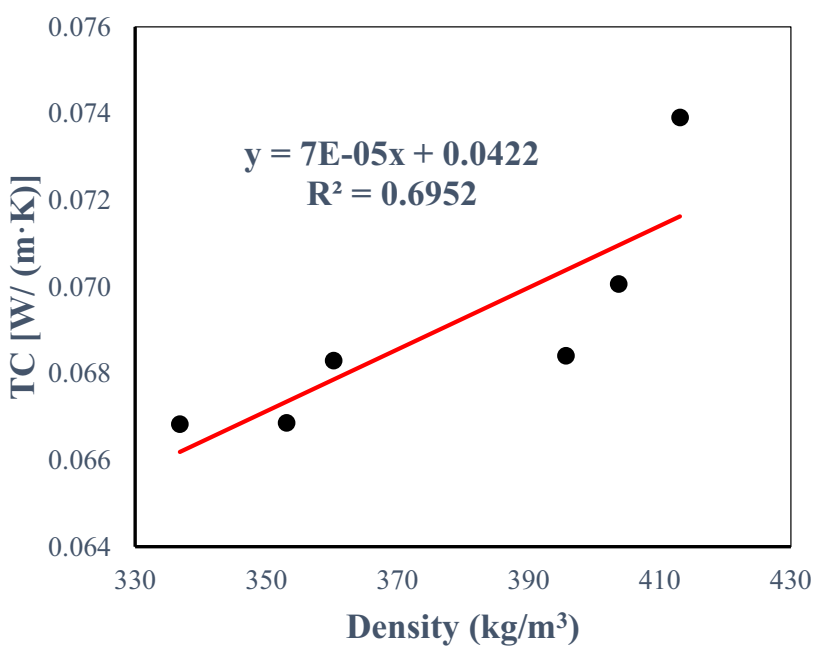

Fig. 3 Linear regression model between density and the thermal conductivity of overlaid bark-based panels (confidence level 95\%)

of P1. However, the results showed that P2 type overlaid panels demonstrated the worst overall performance, including water immersion properties and mechanical behaviour.

The observed differences of the overlaid paper sheets can be explained by the structural characteristics of the investigated papers. These structural features (such as grammage, type of pulp, manufacturing conditions, additives and/or coating etc.) influence the penetration of UF resin, the quality of interphase bonding, the water uptake behaviour and therefore, indicating a strong overall effect on the performance of bark-based panels. This outcome is further enhanced by the discrepancy noticed between the paper sheets as well as their surfaces. The lower CA and negative $\Delta G_{i}$ values observed on the glued surface of recycled paper 

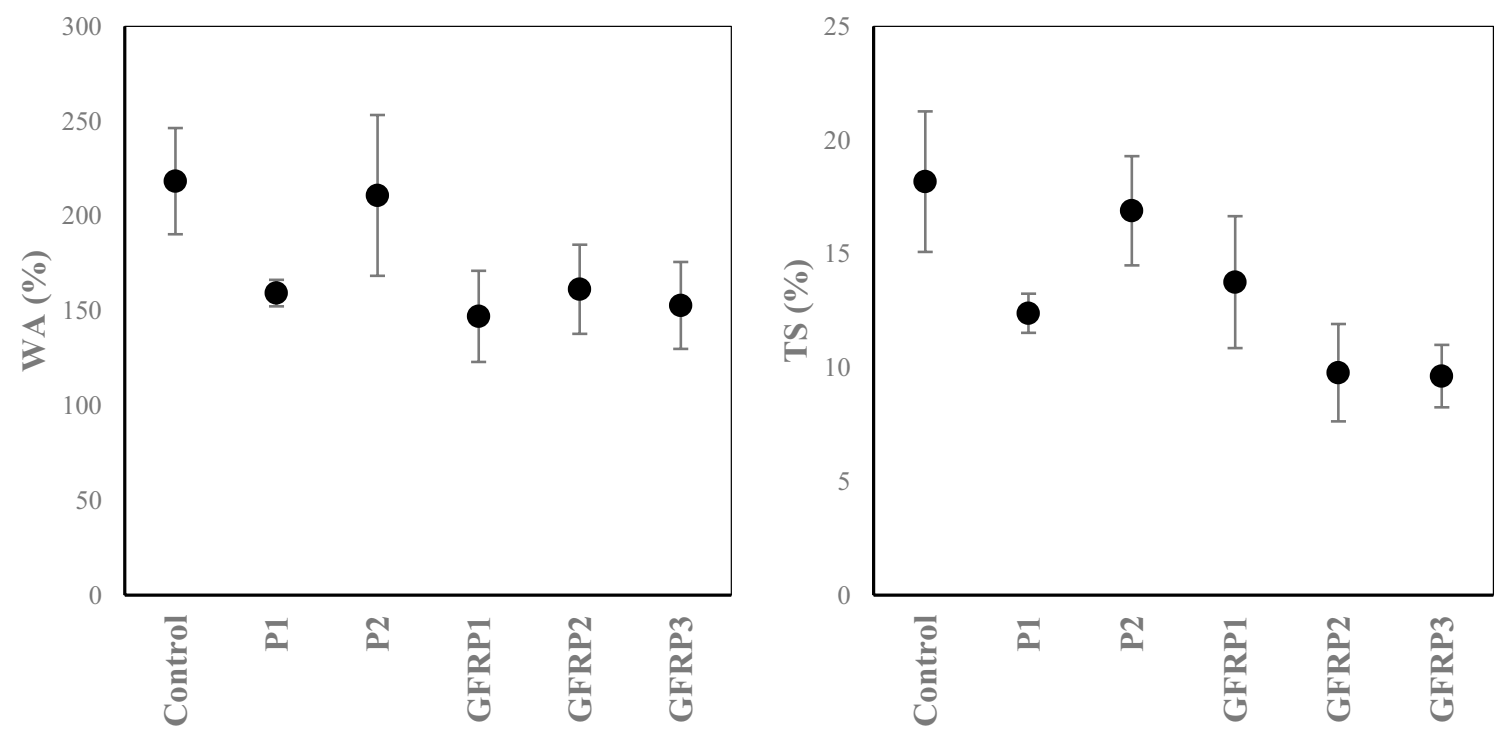

Fig. 4 Water absorption (WA) and thickness swelling (TS) percentages after $24 \mathrm{~h}$ water immersion dependent on paper and fibreglass type

indicate the most favourable wettability, in contrast to the higher CA and positive $\Delta G_{i}$ calculated for the remaining paper surfaces and the coated thermomechanical pulp.

On the contrary, application of fibreglass and epoxy resin bonding on the surfaces of bark-based panels, appeared to significantly minimize and restrain the magnitude of water absorption and thickness swelling (Fig. 4). Aside from their low thermal conductivity, glass fibres appear to have very high specific strength and sound absorption properties, are lightweight, and exhibit very good durability and water vapor resistance behaviour (Cao et al. 2015). Among these three fibreglass types, fibreglass woven fabric and mat revealed improved values compared to fibreglass mesh. The incorporation of GFRP2 and GFRP3 types led to a significant decrease in thickness swelling and water absorption up to $46.20-47.03 \%$ and $26.02-30.01 \%$, respectively.

Even though bark is less hygroscopic than wood, water flux and humidity sorption and desorption behaviour of bark panels play an essential role in the heating energy consumption of buildings (Kain et al. 2018). Therefore, diffusion properties, usually expressed by the water vapour resistance factor ( $\mu$-value), are another important attribute of characterizing insulation materials. Like thermal conductivity, sorption behaviour and water diffusion of wood-based panels are influenced by several factors. Among these factors, panel density, moisture content (relative humidity) and temperature are the most crucial.

Sonderegger and Niemz (2009) investigated the water vapour resistance and diffusion coefficient values of several commercial wood-based panels with different densities and thicknesses. Results have shown that the water vapour resistance factor of the wood-based materials increased with increasing density and decreases with increasing moisture content. Further, an influence of the coefficients of variation range on the values of water vapour flux was also revealed among the wood-based panels (such as OSB, plywood, coated and uncoated boards), due to the diverse particle sizes among the wood-based panels or the bonding interaction of the coated or overlaid boards.

Kain et al. (2018) concluded that the vapour flow through larch bark insulation panels was significantly influenced by the panel structure of void, and that the most important factor influencing the water vapour diffusion resistance was board density. According to these authors (Kain et al. 2018), the panel structure, in terms of particle orientation and particle size, proved to have a minor influence on the panel's vapour permeability, which could be a result of low variation. However, fine particles presented a lower compression resistance compared to coarse ones and are possibly compressed more strongly during hot pressing, thus affecting the density of panels.

Wu and Suchsland (1996) examined the effect of moisture content and gradient of overlaid three-layer hardwood particleboards. Their results revealed that the particleboard core layer had a larger water diffusion coefficient than the face layers as a consequence of lower density and larger internal void volume of the core. Even more, they reported that the dominant moisture transfer mechanism in wood-based panels such as particleboard and fibreboard, may be water-vapor diffusion through air-filled pore spaces, while in solid wood bound water diffusion may play a more important role. In addition, wood and bark anatomical cell characteristics have been shown to influence sorption behaviour of wood and wood-based panels. For instance, Neimsuwan et al. (2008) indicated that earlywood of small loblolly pine had greater sorption rates and diffusion coefficients than latewood, while 
Kain et al. (2018) cited an investigation in which the vapour diffusion through the periderm of hemlock was studied. According to the study findings, White (1979) indicated that the thin-walled periderm tissue sorbs water about three times slower and the thick-walled one thirty times slower than the wood xylem, as reported by Kain et al. (2018).

In this study, the processing parameters and conditions were identical. Therefore, it is believed the high levels of water absorption, which were observed, can be explained by the following reasons: (a) the low panel density, as well as the size and shape of internal panel voids; (b) poplar bark thicknesses (proportion of phloem and periderm) and intrinsic anatomical characteristics (cell types and dimensions), and (c) surface area, density and aspect ratio of bark particles. Thermal or chemical modification of particles or panels would improve their dimensional stability and hygroscopicity.

Besides bark hygroscopicity, absorption of water is assumed to have a major impact on the mechanical performance of gluelines between fiberglass overlays and epoxy resins and consequently on the mechanical performance of overlaid fiberglass bark panels. As water moves inside the wood, the gluelines might act as barriers that are potentially leading to local moistening (Wimmer et al. 2013) and water molecules can easily migrate into the adhesive and modify its chemical and physical properties (Maggana and Pissis 1999). The transport of moisture in epoxy resin systems in moist or humid environments is of great importance, since most epoxies absorb between 1 and $7 \mathrm{wt} \%$ moisture (Soles and Yee 2000). Yet, epoxy was selected as most appropriate for bonding fiberglass with bark. Experiments on the vapor sorption isotherms of common, cured wood adhesives showed an $18 \%, 22 \%, 10 \%$ and $3.5 \%$ moisture uptake of phenol-resorcinol-formaldehyde (PRF), melamine-formaldehyde (MUF), polyvinyl acetate (PVAc) and polyurethane (PU) films, respectively. Moreover, PRF and MUF were classified as slow absorbing adhesives with low diffusion coefficients, PU as medium absorbing adhesives and PVAc as fast absorbing (Wimmer et al. 2013).

\subsection{Mechanical properties}

The measured mechanical properties of the paper and fibreglass overlaid panels indicated very much alike tendencies to their physical properties (Table 2). The variations in static bending properties, i.e. flexural strength (MOR) and flexural modulus of elasticity (MOE), as well as surface soundness (SS) as a function of overlaid type are illustrated in Fig. 5. It was observed that the examined mechanical properties were significantly influenced by the type of overlaying material. Still, it can be reported that fibreglass overlaid panels demonstrated improved values compared to paper overlaying sheets.

The observed differences among the overlaying GFRP and paper mats can be explained by the influence of the inherent properties of fibres itself, the volume fraction and orientation of adherent fibres to the matrix, the type of used resins in this research and their manufacturing processes. In the case of the two paper types bonded with UF resin on the bark-based boards, recycled paper sheet exhibited enhanced mechanical properties compared to the coated TMP paper sheet. Nevertheless, none of these paper sheets resulted in satisfying mechanical performance outcomes, same as their water absorption and thickness swelling values. On the contrary, in terms of the tested fibreglass types, fibreglass woven fabric exhibited the best mechanical behaviour regarding fibreglass mesh and mat reinforcements. However, similar mechanical properties were obtained for both fibreglass mesh and mat types.

More specifically, GFRP3 samples resulted in (i) the lowest thermal conductivity values, (ii) the lowest water immersion properties, and (iii) the highest mechanical properties of all the proposed panels. This may be due to the differences in the fibreglass type structures as determined by the porosity, the glass fibre diameter distribution and the resin applied to these polymeric materials. Based on SEM images, it is assumed by the authors, that glass fibres appear loose 'knitted' in the case of woven fabric with on indication of any resin, while in the other two types, there is an apparent existence of embedded resin through the glass fibers. Even more, it was found that the modulus of rupture of all fibreglass types was higher than the values required by the European standard EN 622-4 (2009), type SB. However, it was shown that fibreglass mesh could not satisfy the required thickness swelling values, which possibly can be explained by its grid sized net format.

The good mechanical performance of the fibreglass bark-based panels could be attributed to the good adhesion between GFRP and bark particles. As reported by Raftery et al. (2009a), epoxy adhesives are generally accepted as appropriate binder to form good quality GFRP-wood bonds in dry conditions. It was also noted that the integrity of the bond depends not only on the epoxy but also on bondline thickness and the glass fibre reinforcing type (Raftery et al. 2009b).

However, in most of the cases, the results were associated with a high standard deviation, which demonstrates the degree of variation in the obtained properties of these specimens. This phenomenon can presumably be explained by the major difficulty in obtaining manually preformed pressed panels with a homogeneous distribution. Another possible reason for this observation might be the amount of the proportions of outer and inner bark and differences 

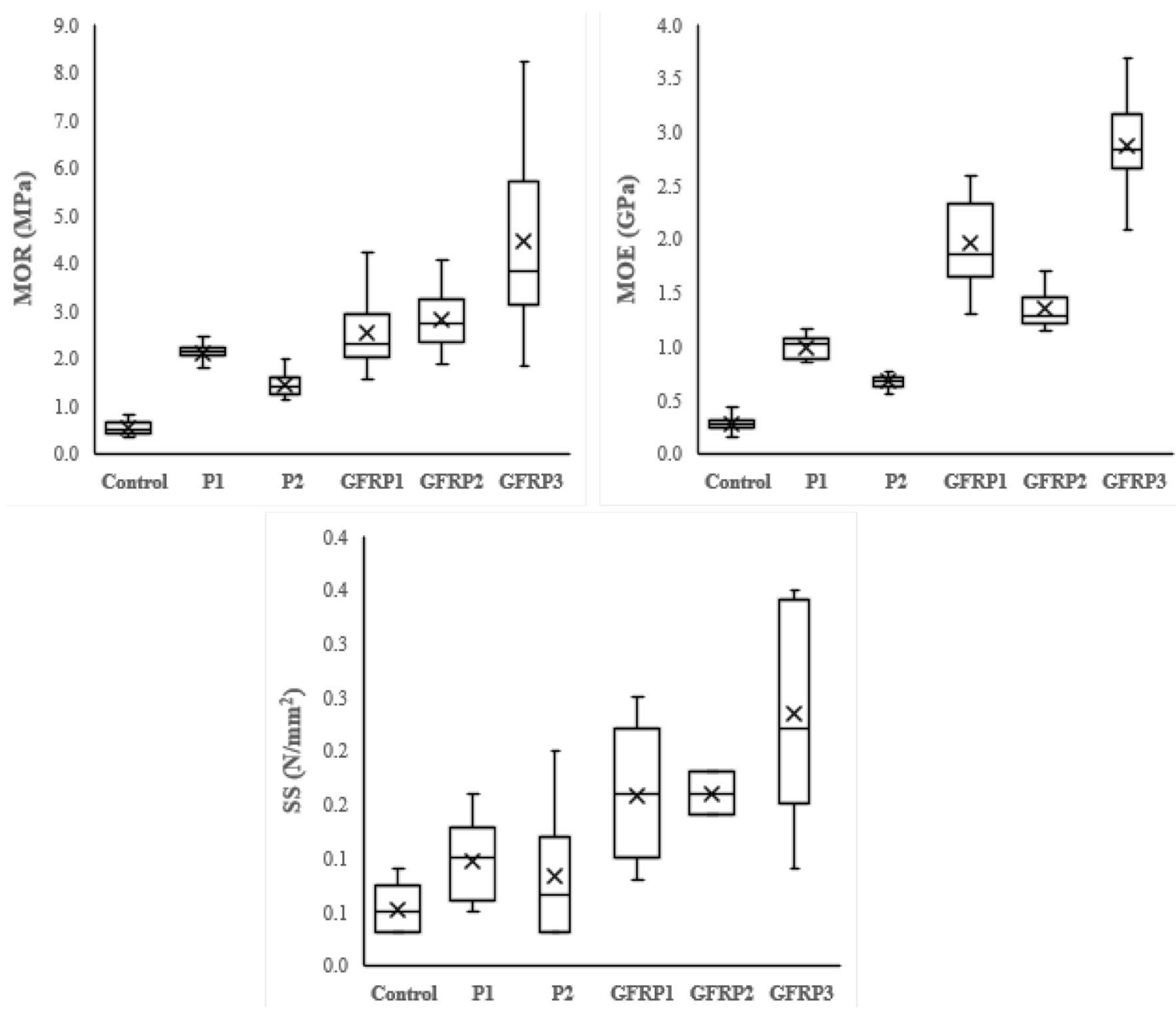

Fig. 5 Flexural strength (MOR), modulus of elasticity (MOE) and surface soundness (SS) of overlaid bark-based panels

in their cellular types and chemical compositions (Eberhard 2013).

\section{Conclusion}

The thermal, physical and mechanical properties of five overlaid bark-based panels were investigated in this work. Three fibreglass types and two paper sheets were used as exterior reinforcements to enhance the stiffness and strength of the bark-based core layers. Thermal conductivity is one of the most important properties for a thermal insulating material. The observed thermal conductivity values were found to be similar to literature values, and indicated an intermediate thermal performance. Consequently, these fibreglass type overlaid panels could potentially be used as insulating panels for thermal insulation of walls. Even more, the results have shown that fibreglass woven fabric and mat types could fulfil the values required by the European standard EN 622-4, type SB.
Nevertheless, further product development is required to evaluate the water sorption, fire and durability behaviour of the proposed insulation panels.

Acknowledgements Open access funding provided by University of Sopron (SOE). This work was supported by the 'Sustainable Raw Material Management Thematic Network-RING 2017', under grant EFOP-3.6.2-16-2017-00010 project in the framework of the Széchenyi 2020 Program. The realization of this project is supported by the European Union, co-financed by the European Social Fund.

\section{Compliance with ethical standards}

Conflict of interest The authors declare that they have no conflict of interest.

Open Access This article is distributed under the terms of the Creative Commons Attribution 4.0 International License (http://creativeco mmons.org/licenses/by/4.0/), which permits unrestricted use, distribution, and reproduction in any medium, provided you give appropriate credit to the original author(s) and the source, provide a link to the Creative Commons license, and indicate if changes were made. 


\section{References}

Asdrubali F, D'Alessandro F, Schiavoni S (2015) A review of unconventional sustainable building insulation materials. Sustain Mater Technol 4:1-17. https://doi.org/10.1016/j.susmat.2015.05.002

Aydin I, Demirkir C, Colak S, Colakoglu G (2017) Utilization of bark flours as additive in plywood manufacturing. Eur J Wood Prod 75:63-69. https://doi.org/10.1007/s00107-016-1096-0

Bal BC (2014) Flexural properties, bonding performance and splitting strength of LVL reinforced with woven glass fiber. Constr Build Mater 51:9-14. https://doi.org/10.1016/j.conbuildma t.2013.10.041

Biblis EJ (1965) Analysis of wood-fibreglass composite beams within and beyond the elastic region. For Prod J 15(2):81-88

Biblis EJ, Carino HF (2000) Flexural properties of southern pine plywood overlaid with fibreglass-reinforced plastic. For Prod J 50(4):34-36

Bøhmer E (2001) Thermal properties. In: Borch J, Lyne MB, Mark RE, Habeger CC (eds) Handbook of physical testing of paper, vol 2. CRC Press, New York, pp 389-427

Cai Z (2006) Selected properties of MDF and flakeboard overlaid with fibreglass mats. For Prod J 56(11/12):142-1466

Cao X, Liu JJ, Cao XD, Li Q, Hu E, Fan FH (2015) Study of the thermal insulation properties of the glass fiber board used for interior building envelope. Energy Build 107:49-58. https://doi. org/10.1016/j.enbuild.2015.08.007

Eberhard T (2013) Longleaf pine inner bark and outer bark thicknesses: measurement and relevance. South J Appl For 37(3):177-180. https://doi.org/10.5849/sjaf.12-023

EN 310 (1993) Wood-based panels: determination of modulus of elasticity in bending and of bending strength European Committee for Standardisation (CEN), Brussels

EN 311 (1993) Wood-based panels: surface soundness—test method. European Committee for Standardisation (CEN), Brussels

EN 317 (1993) Particleboards and fibreboards-determination of swelling in thickness after immersion in water. European Committee for Standardisation (CEN), Brussels

EN 323 (1993) Wood-based panels: determination of density. European Committee for Standardisation (CEN), Brussels

EN 326-1 (1994) Wood-based panels: sampling, cutting and inspection Part 1: Sampling and cutting of test pieces and expression of test results. European Committee for Standardization (CEN), Brussels

EN 622-4 (2009) Fibreboards—specifications-part 4: requirements for softboards. European Committee for Standardisation (CEN), Brussels

Kain G, Barbu MC, Hinterreiter S, Richter K, Petutschnigg A (2013) Using bark as a heat insulation material. BioResources 8(3):3718-3731

Kain G, Güttler V, Barbu MC, Petutschnigg A, Richter K, Tondi G (2014) Density related properties of bark insulation boards bonded with tannin hexamine resin. Eur J Wood Prod 72(4):417-424. https://doi.org/10.1007/s00107-014-0798-4

Kain G, Lienbacher B, Barbu MC, Senck S, Petutschnigg A (2018) Water vapour diffusion resistance of larch (Larix decidua) bark insulation panels and application considerations based on numeric modelling. Constr Build Mater 164:308-316. https://doi. org/10.1016/j.conbuildmat.2017.12.212

Lavrykov SA, Ramarao BV (2012) Thermal properties of copy paper sheets. Dry Technol 30(3):297-311. https://doi.org/10.1080/07373 937.2011.638148

Liu LF, Li HQ, Lazzaretto A, Manente G, Tong CY, Liu GB, Li NP (2017) The development history and prospects of biomass-based insulation materials for buildings. Renew Sustain Energy Rev 69:912-932. https://doi.org/10.1016/j.rser.2016.11.140
Maggana C, Pissis P (1999) Water sorption and diffusion studies in an epoxy resin system. J Polym Sci Pol Phys 37(11):1165-1182. https://doi.org/10.1002/(SICI)1099-0488(19990601)37:11\%3c116 5:AID-POLB11\%3e3.0.CO;2-E

Martin RE (1963) Thermal properties of bark. For Prod J 13(10):419-426

Mitzner RC (1973) Durability and maintenance of plywood overlaid with fibreglass reinforced plastic. Am. Plywood Assoc Res. Report No. 119 part 3

Moradpour P, Pirayesh H, Gerami M, Jouybari IR (2018) Laminated strand lumber (LSL) reinforced by GFRP; mechanical and physical properties. Constr Build Mater 158:236-242. https://doi. org/10.1016/j.conbuildmat.2017.09.172

Nakaya T, Yamasaki M, Fukuta S, Sasaki Y (2016) Thermal conductivity and volumetric specific heat of low-density wooden mats. For Prod J 66(5-6):300-307

Neimsuwan T, Wang S, Taylor AM, Rials TG (2008) Statics and kinetics of water vapor sorption of small loblolly pine samples. Wood Sci Technol 42(6):493-506. https://doi.org/10.1007/ s00226-007-0165-2

Osmannezhad S, Faezipour M, Ebrahimi G (2014) Effects of GFRP on bending strength of glulam made of poplar (Populus deltoids) and beech (Fagus orientalis). Constr Build Mater 51:3439. https://doi.org/10.1016/j.conbuildmat.2013.10.035

Pásztory Z, Mohácsiné IR, Gorbacheva G, Börcsök Z (2016) The utilization of tree bark. Bioresources 11(3):7859-7888

Pásztory Z, Mohácsiné IR, Börcsök Z (2017) Investigation of thermal insulation panels made of black locust tree bark. Constr Build Mater 147:733-735. https://doi.org/10.1016/j.conbuildma t.2017.04.204

Pavel CC, Blagoeva DT (2018) Competitive landscape of the EU's insulation materials industry for energy-efficient buildings. PUBSY No. JRC108692 EUR 28816 EN, Publications Office of the European Union, Luxemburg

Raftery GM, Harte AM, Rodd PD (2009a) Bond quality at the FRP-wood interface using wood-laminating adhesives. Int J Adhes Adhes 29:101-110. https://doi.org/10.1016/j.ijadh adh.2008.01.006

Raftery GM, Harte AM, Rodd PD (2009b) Bonding of FRP materials to wood using thin epoxy gluelines. Int J Adhes Adhes 29:580-588. https://doi.org/10.1016/j.ijadhadh.2009.01.004

Schiavoni S, D'Alessandro F, Bianchi F, Asdrubali F (2016) Insulation materials for the building sector: a review and comparative analysis. Renew Sustain Energy Rev 62:988-1011. https://doi. org/10.1016/j.rser.2016.05.045

Soles CL, Yee AF (2000) A discussion of the molecular mechanisms of moisture transport in epoxy resins. J Polym Sci Pol Phys 38(5):792-802. https://doi.org/10.1002/(SICI)1099-0488(20000 301)38:5\%3c792:AID-POLB16\%3e3.0.CO;2-H

Sonderegger W, Niemz P (2009) Thermal conductivity and water vapour transmission properties of wood-based materials. Eur J Wood Prod 67(3):313-321. https://doi.org/10.1007/s0010 7-008-0304-y

Sonderegger W, Niemz P (2012) Thermal and moisture flux in soft fibreboards. Eur J Wood Prod 70(1-3):25-35. https://doi. org/10.1007/s00107-010-0498-7

TAPPI T 494 (1996) Tensile Breaking Properties of Paper and Paperboard. Technical Assoc. Pulp and Paper Industry, Atlanta-GA

TAPPI T 410 (1998) Grammage of Paper and Paperboard (Weight per Unit Area). Technical Assoc. Pulp and Paper Industry, Atlanta-GA

TAPPI T 458 (2004) Surface Wettability of Paper (Angle of Contact Method). Technical Assoc. Pulp and Paper Industry, Atlanta-GA

Torres-Rivas A, Palumbo M, Haddad A, Cabeza LF, Jiménez L, Boer D (2018) Multi-objective optimisation of bio-based thermal insulation materials in building envelopes considering condensation 
risk. Appl Energy 224:602-614. https://doi.org/10.1016/j.apene rgy.2018.04.079

Troppová E, Švehík M, Tippner J, Wimmer R (2015) Influence of temperature and moisture content on the thermal conductivity of wood-based fibreboards. Mater Struct 48(12):4077-4083. https:// doi.org/10.1617/s11527-014-0467-4

Tudor EM, Barbu MC, Petutschnigg A, Reh R (2018) Added-value for wood bark as a coating layer for flooring tiles. J Clean Prod 170:1354-1360. https://doi.org/10.1016/j.jclepro.2017.09.156

Wangaard FF (1964) Elastic deflection of wood-fibreglass composite beams. For Prod J 14(6):256-260

White MS (1979) Water vapor diffusion through eastern hemlock periderm. Wood Fiber Sci 11(3):171-178
Wimmer R, Klausler O, Niemz P (2013) Water sorption mechanisms of commercial wood adhesive films. Wood Sci Technol 47(4):763775. https://doi.org/10.1007/s00226-013-0538-7

Wu QL, Suchsland O (1996) Prediction of moisture content and moisture gradient of an overlaid particleboard. Wood Fiber Sci 28(2):227-239

Publisher's Note Springer Nature remains neutral with regard to jurisdictional claims in published maps and institutional affiliations. 